\title{
Rancang Bangun Purwarupa Sistem Rekam Medik Portable
}

\author{
Gratia C. Pondaag, Xaverius Najoan, Alwin Sambul \\ Teknik Informatika Universitas Sam Ratulangi Manado, Indonesia. \\ gratiacpondaag@gmail.com, xnajoan@unsrat.ac.id, asambul@unsrat.ac.id
}

\begin{abstract}
Abstrak - Berdasarkan Peraturan Menteri Kesehatan Republik Indonesia tahun 2008, rekam medik adalah berkas yang berisikan identitas pasien, pemeriksaan, pengobatan, tindakan dan pelayanan lain yang telah diberikan kepada pasien. Di Indonesia, sebagian besar rekam medik pasien hanya ada di rumah sakit atau dokter praktek tempat pasien pernah memeriksakan kesehatannya. Hal ini membuat riwayat penyakit pasien beserta obat-obatan yang pernah dikonsumsi tidak diketahui saat pasien harus berganti dokter atau rumah sakit. Kondisi ini dapat menyebabkan dokter mengambil keputusan yang kurang tepat karena ketidaktahuannya akan riwayat kesehatan pasien.

Penelitian ini bertujuan untuk merancang dan membangun purwarupa sistem rekam medik portable. Dengan adanya sistem ini, saat pasien dirawat di rumah sakit lain ataupun memeriksakan kesehatan di dokter praktek lain, dokter bisa memberikan penanganan yang tepat. Hal ini dikarenakan data mengenai riwayat penyakit pasien dan obat-obatan yang pernah dikonsumsi tersimpan dalam rekam medik portable.

Penelitian ini diawali dengan pengumpulan data berupa model-model rekam medik yang digunakan pada rumah sakit, puskesmas, dan klinik. Data tersebut digunakan untuk menghasilkan suatu aplikasi sistem rekam medik yang dapat membuat dan membaca data rekam medik yang tersimpan dalam flashdisk.
\end{abstract}

Setelah selesai dibangun, aplikasi kemudian diuji menggunakan metode Blackbox testing. Hasilnya menunjukkan cara kerja dari aplikasi telah berjalan sesuai dengan yang telah direncanankan sebelumnya.

Kata Kunci: Rekam medik, Medikal record, Database, Sistem Rekam Medik

\section{PENDAHULUAN}

Berdasarkan Peraturan Menteri Kesehatan Republik Indonesia tahun 2008, Rekam medik adalah berkas yang berisikan catatan dan dokumen tentang identitas pasien, pemeriksaan, pengobatan, tindakan dan pelayanan lain yang telah diberikan kepada pasien. Di sisi lain menurut UU No. 29 tahun 2004 tentang Praktik Kedokteran Pasal 52 "Pasien, dalam menerima pelayanan pada praktik kedokteran, mempunyai hak untuk meminta pendapat dokter atau dokter gigi lain dan mendapatkan isi rekam medik. Melihat kedua hal di atas bisa dikatakan bahwa rekam medik adalah berkas atau catatan penting yang harus dimiliki juga oleh pasien, bukan hanya pihak rumah sakit ataupun dokter praktek.

Namun, selama ini yang terjadi adalah rekam medik pasien hanya ada di rumah sakit tempat pasien pernah dirawat atau dokter praktek, tempat pasien pernah memeriksakan kesehatan sebelumnya. Rekam medik yang hanya ada di satu tempat membuat riwayat penyakit pasien beserta dengan obat-obatan yang pernah dikonsumsi tidak diketahui saat berganti dokter atau rumah sakit, hal ini dapat menyebabkan dokter mengambil keputusan yang kurang tepat karena ketidaktahuannya akan riwayat kesehatan pasien.

Melihat permasalahan yang ada, penting untuk membuat suatu sistem rekam medik portable yang bisa di bawa oleh pasien dan memudahkan pasien untuk berobat dimana saja. Saat pasien dirawat dirumah sakit lain ataupun memeriksakan kesehatan di dokter praktek lain, dokter bisa memberikan penanganan yang tepat, sesuai dengan riwayat penyakit pasien dan obat-obatan yang pernah dikonsumsi, karena data tersebut tersimpan dalam rekam medik portable

\section{LANDASAN TEORI}

\section{A. Rekam Medik}

Peraturan Menteri Kesehatan Republik Indonesia tahun 2008 Pasal 1 menjelaskan rekam medik adalah berkas yang berisikan catatan dan dokumen tentang identitas pasien, pemeriksaan, pengobatan, tindakan dan pelayanan lain yang telah diberikan kepada pasien.

Dalam Peraturan Menteri Kesehatan No. 749 a tahun 1989 menyebutkan bahwa rekam medik memiliki 5 manfaat, yaitu :

1. Sebagai dasar pemeliharaan kesehatan dan pengobatan pesien

2. Sebagai bahan pembuktian dalam perkara hokum

3. Bahan untuk kepentingan penelitian

4. Sebagai dasar pembayaran biaya pelayanan kesehatan

5. Sebagai bahan untuk menyiapkan statistik kesehatan

\section{B. Perkembangan Pencatatan Rekam Medik}

Rekam medik saat ini dicatat secara manual dan di tulis dikertas. Format standar rekam medik yang ada saat ini memberikan kesempatan kepada dokter untuk mencatat data dalam bentuk naratif yang minimum format. Penyimpanan dilakukan secara manual yang rentan kerusakan sesuai dengan umur kertas.

Data rekam medik yang ditulis di kertas akan cukup sulit untuk dipindahkan. Pada kasus kasus mendesak dimana pasien harus ditangani dengan cepat maka tidak dimungkinkan untuk mengambil data rekam medik dari rumah sakit asal dimana pasien tersebut biasa di tangani. Bagi pasien yang biasa berpindah tempat kemungkinan besar catatan mediknya akan tersebar di berbagai rumah sakit yang telah memberikan pelayanan kesehatan kepada pasien tersebut.

Beberapa rumah sakit modern telah dicoba mengalihkan metode pancatatan rekam medik ini ke dalam media digital dan disimpan di server rumah sakit 
yang bersangkutan. Namun terdapat permasalahan disini yaitu apakah ada sarana komunikasi data yang cukup memadai untuk proses transfer data. Kemudian permasalahan yang juga muncul adalah kompatibilitas format data. Walaupun transfer data dapat dilakukan akan tetapi belum tentu rumah sakit tujuan dapat membaca data yang ditransfer dengan baik [5].

\section{Rekam Medik Elektronik}

Melihat pentingnya sebuah rekam medik, maka sudah saatnya semua rumah sakit di Indonesia membangun Rekam Medik Elektronik (RME) dan akan lebih berdaya guna jika semua rekam medik itu terkoneksi didalam jaringan komputer seluruh rumah sakit di Indonesia

RME adalah penggunaan perangkat teknologi informasi untuk pengumpulan, penyimpanan, pengolahan serta pengaksesan data yang tersimpan pada rekam medik pasien di rumah sakit dalam suatu sistem manajemen basis data yang menghimpun berbagai sumber data medik. Bahkan beberapa rumah sakit modern telah menggabungkan RME dengan aplikasi Sistem Informasi Manajemen Rumah Sakit (SIMRS) yang merupakan aplikasi induk yang tidak hanya berisi RME tetapi sudah ditambah dengan fitur-fitur lainnya[1].

\section{Flashdisk}

Flashdisk merupakan alat penyimpan data berukuran mini yang dapat digunakan untuk memindahkan data dari komputer ke piranti lainnya. Meskipun bentuknya kecil, alat itu dapat menyimpan data berukuran besar. Ukuran flashdisk sangat bervariasi, mulai dari yang berukuran besar sampai ukuran yang sangat kecil. Desain dan bentuknya pun sangat beragam. Ada yang berbentuk balok, bola, mobil-mobilan dan ada juga yang menyerupai bentuk kalung dan gantungan kunci. Karena keunikan bentuk dan desain flashdisk tersebut, selain fungsi utamanya untuk menyimpan dan mentransfer data flashdisk juga bisa dibawa dengan cara dipakai sebagai kalung atau gantungan kunci [9].

Flashdisk adalah media penyimpanan data portable yang berbentuk USB. Ukurannya kecil dan bobotnya sangat ringan, tetapi dapat menyimpan data dalam jumlah besar. Kelebihan flashdisk dibanding alat penyimpan data lainnya yaitu harddisk adalah bentuknya yang berukuran kecil dan praktis serta dapat digunakan dengan mudah [7].

\section{E. SQLite}

SQLite merupakan sebuah perpustakaan proses yang menerapkan kemandirian tanpa server, tidak adanya konfigurasi mesin, dan basis data $S Q L$ transaksional. Kode untuk SQLite berada dalam domain publik dengan demikian bebas untuk digunakan untuk tujuan apapun, komersial atau swasta.

SQLite adalah mesin basis data SQL yang tertanam. Tidak seperti kebanyakan basis data $S Q L$ lainnya, SQLite tidak memiliki proses server yang terpisah. SQLite membaca dan menulis secara langsung ke filedisk biasa[8].

\section{F. Aplikasi Berbasis Desktop}

Aplikasi desktop adalah aplikasi yang dapat berjalan secara sendiri atau independen dalam sistem desktop komputer atau laptop [6]. Menurut Joy, pemilihan aplikasi berbasis desktop biasanya ditujukan kepada mereka yang memiliki koneksi internet yang kurang baik dan sangat peduli dengan keamanan. Indonesia memiliki koneksi internet yang belum cukup bagus dan keamanan yang belum memadai sehingga penulis memilih untuk membangun aplikasi berbasis desktop.

G. Java

Java adalah bahasa pemrograman yang berorientasi objek dan dapat dijalankan pada berbagai platform sistem operasi. Perkembangan Java tidak hanya terfokus pada satu sistem operasi, tetapi dikembangkan untuk berbagai sistem operasi dan bersifat open source.

Aplikasi dengan teknologi Java secara umum adalah aplikasi serbaguna yang dapat dijalankan pada seluruh mesin yang memiliki Java Runtime Environment.[2]

Penulis menggunakan bahasa pemrograman Java karena aplikasi yang dibuat harus dapat dijalankan diberbagai platform seperti Linux, Windows, Mac OS dan Sun Solaris.

\section{METODOLOGI PENELITIAN}

\section{A. Objek dan Lokasi Penelitian}

Pengumpulan data akan dilakukan di beberapa rumah sakit dan tempat praktek dokter di Manado. Data yang akan di kumpulkan berupa bentuk umum rekam medik yang digunakan.

\section{B. Langkah-langkah Penelitian}

Langkah-langkah yang dilakukan penulis dalam penelitian ini tergambar dalam kerangka berpikir seperti pada gambar 1 .

\section{Gambar 1. Kerangka Berpikir}

Pengumpulan data yang dilakukan dalam penelitian ini adalah wawancara. Wawancara dilakukan dengan dokter praktek ataupun petugas rumah sakit yang berwenang menyimpan rekam medik. Pengumpulan data dengan teknik wawancara dilakukan untuk mengetahui informasi mengenai bentuk rekam medik serta data-data apa saja yang dimasukkan kedalam rekam medik.

Setelah mendapatkan data maka penulis akan mulai merancang basis data, use case dan membuat purwarupa sesuai dengan bentuk rekam medik yang didapatkan. Dalam penelitian ini akan digunakan basis data SQLite yang mendukung portabilitas data.

Setelah purwarupa selesai dibangun akan dilakukan pengujian apakah sistem yang dibuat berjalan sesuai dengan skenario yang diharapkan. Untuk menguji fitur- 
fitur aplikasi sesuai dengan fungsinya maka dilakukan pengujian menggunakan metode Blackbox.

\section{Skenario yang Diharapkan}

Pasien pergi memeriksakan kesehatannya di sebuah rumah sakit dan bertemu dengan dokter, kemudian dokter menggunakan aplikasi untuk mengakses file rekam medik pasien yang berada dalam flashdisk, mengisinya kemudian disimpan. Pasien kemudian pulang dari rumah sakit dengan membawa flashdisk, didalamnya telah ada catatan pemeriksaan yang telah diisi oleh dokter.

Setelah beberapa waktu pasien kemudian pergi memeriksakan kesehatan di rumah sakit lain, pasien bertemu dengan dokter yang memeriksa kesehatannya, kemudian dokter melihat rekam medik pasien yang telah ada didalam flashdisk milik pasien untuk mengetahui riwayat kesehatan pasien. Setelah itu dokter mengisi lagi rekam medik sesuai dengan pemeriksaan yang telah dilakukan.

\section{HASIL DAN PEMBAHASAN}

\section{A. Pengumpulan Data}

Pertama yang dilakukan penulis adalah mengumpulkan data di rumah sakit Pancaran Kasih, Puskesmas Minanga, dan Balai Kesehatan Mata Masyarakat. Data yang dikumpulkan berupa bentuk rekam medik yang selama ini digunakan.

\section{B. Perancangan}

Setelah mendapatkan contoh rekam medik yang digunakan selama ini, penulis memulai perancangan purwarupa. Perancangan yang dilakukan meliputi perancangan basis data, use case diagram, dan user interface

1. Perancangan Basis Data

Berikut ini merupakan struktur basis data yang dirancang sesuai dengan data-data yang ada pada rekam medik

Gambar 2. Skenario yang Diharapkan

\section{Fitur-fitur}

Berikut adalah fitur-fitur yang akan di bangun pada sistem rekam medik portable:

1. Buat data pribadi pasien

Fitur ini digunakan oleh dokter untuk mengisi data-data diri pasien saat pertama kali memeriksakan kesehatannya.

2. Lihat data pribadi pasien

Fitur ini digunakan oleh dokter untuk melihat data pribadi pasien

3. Lihat riwayat pemeriksaan pasien

Fitur ini digunakan oleh dokter untuk melihat riwayat pemeriksaan pasien

4. Tambah catatan pemeriksaan

Fitur ini digunakan oleh dokter untuk menambahkan data kesehatan pasien yang ada dalam rekam medik sebelumnya. 
Tipe data yang digunakan untuk data-data kesehatan pasien adalah text sehingga dapat dienkripsi.

Relasi antar tabel diatas tergambar dalam Entity Relationship Diagram (ERD) seperti pada gambar 5

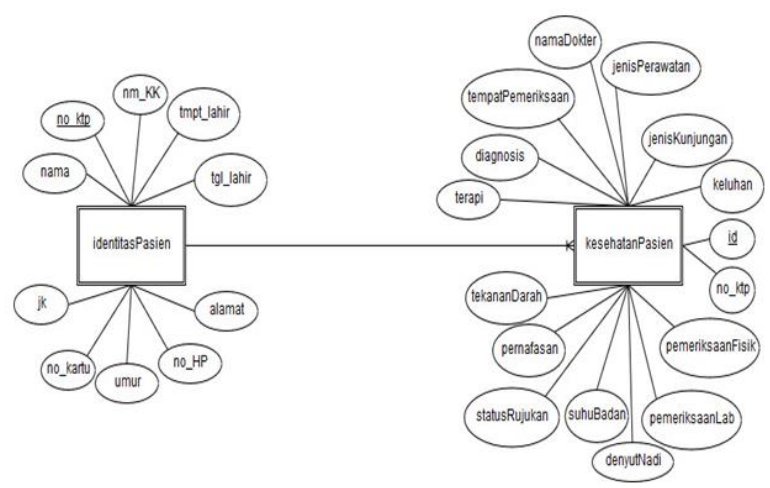

Gambar 5. Entity Relationship Diagram

2. Perancangan use case

Use case diagram digunakan untuk menggambarkan interaksi antara aktor dan sistem. Sistem yang dirancang memiliki satu aktor yang dapat membuat data pribadi, melihat data pribadi, membuat riwayat kesehatan, dan melihat riwayat kesehatan.

Berikut merupakan Use case yang dirancang sesuai dengan fitur-fitur yang dibangun pada purwarupa sistem rekam medik portable.

Gambar 5. Use case diagram

\section{Implementasi \\ Setelah melakukan perancangan sistem penulis kemudian melakukan pengimplementasian dari perancangan yang telah dibuat sebelumnya.}

1. Implementasi Basis Data

Gambar 6. Implementasi Struktur Basis Data

Penulis menggunakan $S Q L$ ite untuk membuat basis data dari sistem yang dibangun. Basis data dibuat sesuai dengan perancangan tabel, atribut, dan tipe data.

\section{Implementasi User Interface}

Penulis menggunakan bahasa pemrograman Java untuk menulis kode program, sehingga aplikasi dapat dijalankan sesuai dengan fitur-fitur yang dirancang.

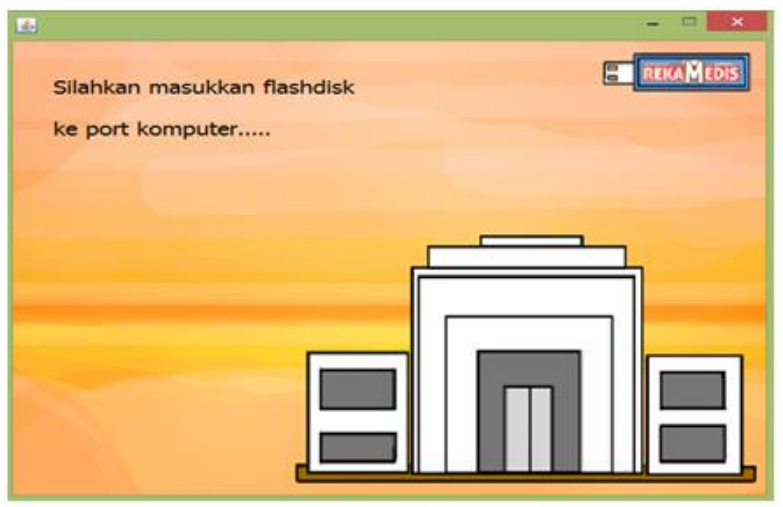

Gambar 7. Tampilan awal aplikasi

Tampilan awal aplikasi setelah dijalankan seperti pada gambar 7, pengguna harus memasukkan flashdisk yang dibawa pasien untuk dapat melanjutkan ke halaman menu.

Setelah flashdisk dimasukkan sistem akan membaca otomatis file rekam medik yang ada di dalam flashdisk. File rekam medik mempunyai nama yang sama sehingga dapat diakses oleh aplikasi. 


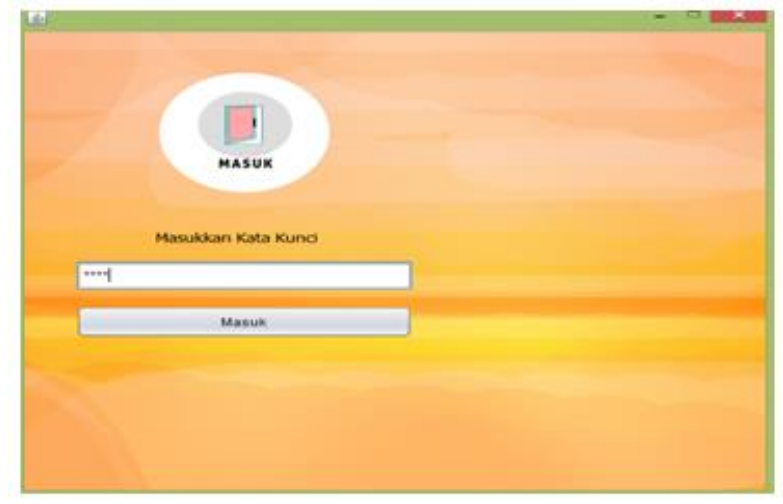

Gambar 8. Halaman Login

Pengguna harus memasukkan password untuk dapat mengakses basis data yang berisi rekam medik pasien.

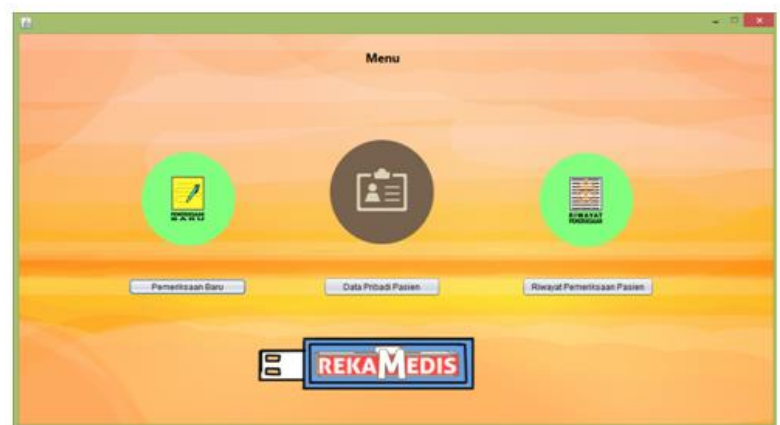

Gambar 9. Tampilan Menu

Setelah pengguna berhasil memasukkan password maka akan muncul halaman menu seperti pada gambar 9 .

Pengguna dapat memilih menu data pribadi untuk mengisi data-data pribadi pasien saat pertama kali datang, tampilannya seperti pada gambar 10 .

Jika pasien sudah pernah memeriksakan diri sebelumnya maka data pribadi pasien sudah tersimpan dan hanya bisa dilihat oleh pengguna, seperti pada gambar 11 .

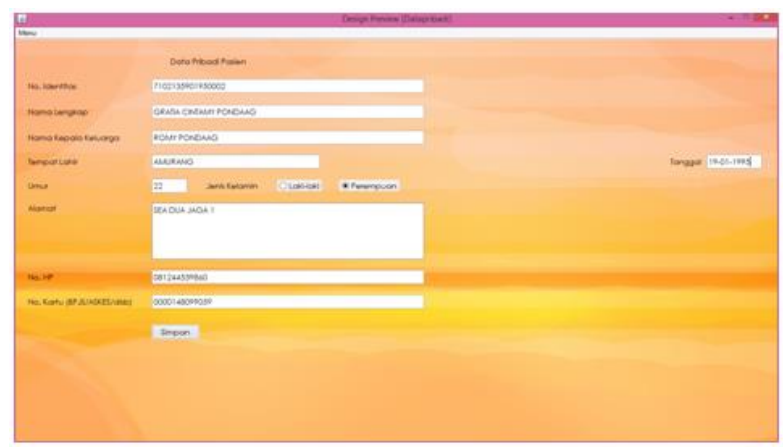

Gambar 10. Menyimpan Data Pribadi Pasien

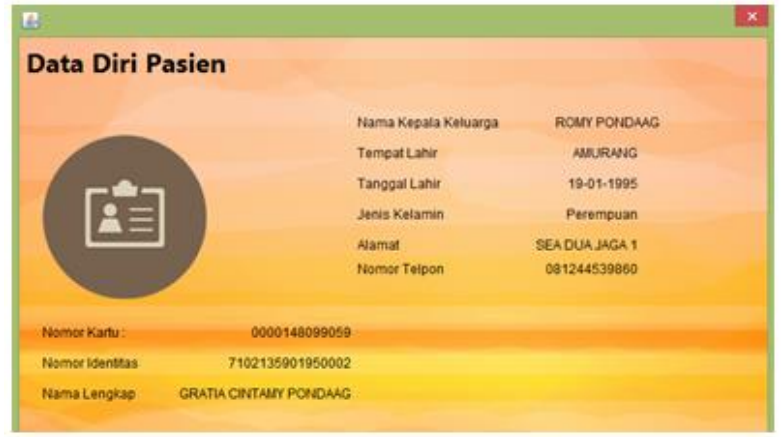

Gambar 11 Melihat Data Pribadi Pasien

Pengguna dapat memilih menu pemeriksaan baru untuk mengisi data-data hasil pemeriksaan pasien seperti pada gambar 12 .

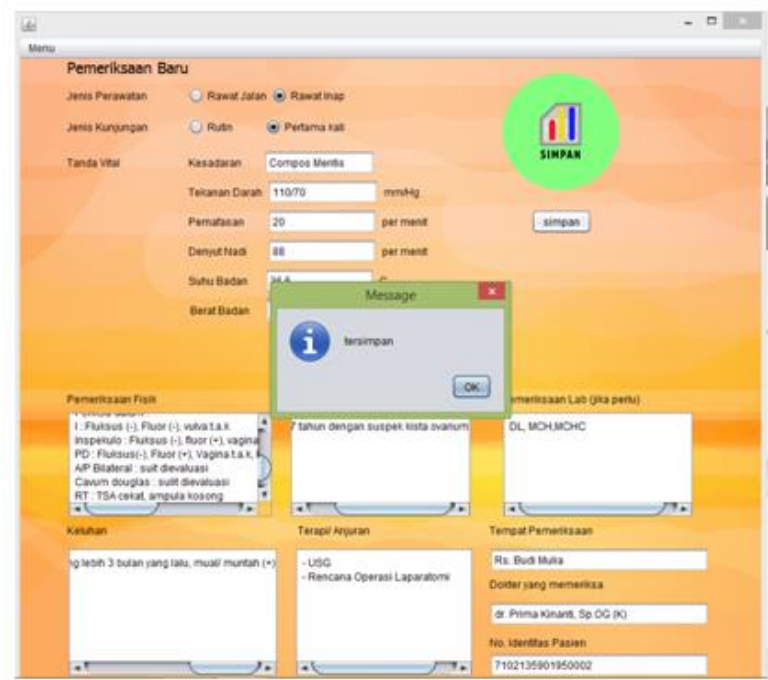

Gambar 12. Tampilan Pemeriksaan Baru

Untuk mengakses informasi mengenai riwayat pemeriksaan yang pernah dilakukan, pengguna dapat memilih menu riwayat kesehatan, tampilannya seperti pada gambar 13 .

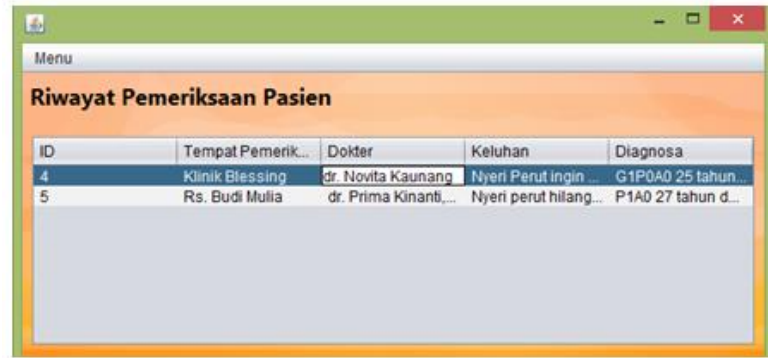

Gambar 13 Tampilan Riwayat Kesehatan

\section{Pengujian}

Penulis menggunakan metode BlackBox Testing untuk menguji cara kerja dari aplikasi apakah sesuai dengan fungsi yang dirancang sebelumnya atau tidak

Pengujian yang dilakukan tergambar pada gambar 14 . 


\begin{tabular}{|c|c|c|c|c|}
\hline No & $\begin{array}{l}\text { Komponen } \\
\text { Pengujian }\end{array}$ & Masukan & Keluaran & Status \\
\hline 1 & Login & $\begin{array}{l}\text { Dokter memasukkan } \\
\text { password dari pasien }\end{array}$ & $\begin{array}{l}\text { Dokter berhasil } \\
\text { masuk dan dapat } \\
\text { mengakses menu }\end{array}$ & Berhasil \\
\hline 2 & $\begin{array}{l}\text { Operasi buat } \\
\text { untuk menu } \\
\text { data pribadi }\end{array}$ & $\begin{array}{l}\text { Dokter } \\
\text { menambahkan data- } \\
\text { data pribadi pasien }\end{array}$ & $\begin{array}{l}\text { Data berhasil } \\
\text { disimpan kedalam } \\
\text { basis data }\end{array}$ & Berhasil \\
\hline 3 & $\begin{array}{l}\text { Operasi } \\
\text { membaca data } \\
\text { pribadi untuk } \\
\text { menu data } \\
\text { pribadi }\end{array}$ & $\begin{array}{l}\text { Dokter melihat data } \\
\text { pribadi pasien }\end{array}$ & $\begin{array}{l}\text { Data pribadi pasien } \\
\text { berhasil ditampilkan }\end{array}$ & Berhasil \\
\hline 4 & $\begin{array}{l}\text { Operasi } \\
\text { membaca } \\
\text { riwayat } \\
\text { pemeriksaan } \\
\text { pasien }\end{array}$ & $\begin{array}{l}\text { Dokter melihat } \\
\text { riwayat pemeriksaan } \\
\text { pasien }\end{array}$ & $\begin{array}{l}\text { Riwayat } \\
\text { pemeriksaan pasien } \\
\text { berhasil ditampilkan }\end{array}$ & Berhasil \\
\hline 5 & $\begin{array}{l}\text { Operasi } \\
\text { membuat hasit } \\
\text { pemeriksaan } \\
\text { baru }\end{array}$ & $\begin{array}{l}\text { Dokter } \\
\text { menambahkan data } \\
\text { hasil pemeriksaan } \\
\text { kesehatan pasien }\end{array}$ & $\begin{array}{l}\text { Hasil pemeriksaan } \\
\text { pasien berhasil } \\
\text { disimpan }\end{array}$ & Berhasil \\
\hline
\end{tabular}

Gambar 14. Tabel Pengujian Sistem

\section{PENUTUP}

\section{A. Kesimpulan}

Setelah melakukan perancangan, implementasi dan pengujian maka didapatlah kesimpulan bahwa purwarupa sistem rekam medik portable telah berhasil dibangun. Rekam medik tersimpan di flashdisk yang dimiliki pasien dalam bentuk file $S Q L$, sehingga dapat dibawa-bawa untuk pemeriksaan kesehatan.

Purwarupa memiliki fitur untuk membuat catatan medik baru sesuai dengan pemeriksaan yang telah dilakukan, melihat riwayat pemeriksaan pasien, mengisi dan juga melihat data diri pribadi pasien.

Purwarupa yang dibangun dapat berjalan di semua platform sehingga dapat digunakan oleh dokter di komputer dengan sistem operasi Linux, Windows, Mac OS dan Sun Solaris.

\section{B. Saran}

Saran untuk penelitian selanjutnya agar aplikasi ini dapat terus dikembangkan:

1. Dapat menambahkan data berupa gambar dalam basis data dengan mempelajari literatur "penggunaan format dicom untuk mengatasi perbedaan kompatibilitas dalam penyimpanan data rekam medis", yang ditulis oleh Budhi Kristianto yang menjelaskan tentang bagaimana gambar dapat dengan mudah di masukkan dalam rekam medis dan dapat di baca oleh aplikasi itu sendiri.

2. Dapat ditambahkan beberapa field lagi sesuai dengan kebutuhan kelengkapan rekam medik selanjutnya.

3. Dapat diintegrasikan dengan basis data rumah sakit atau menambahkan menu untuk mencetak sehingga bisa digunakan juga untuk keperluan rumah sakit, dokter ataupun puskesmas sebagai penyedia layanan kesehatan.

\section{DAFTAR PUSTAKA}

[1] Handiwidjojo Wimmie. 2015. Rekam Medis Elektronik. Program Studi Teknik Informatika Universitas Kristen Duta Wacana Yogyakarta.

[2] Ifan. 2015. Alarm Kebakaran Berbasis Citra. Universitas Tadulako Palu.

[3] Republik Indonesia. 2008. Peraturan Menteri Kesehatan Republik Indonesia Nomor 269 tentang Rekam Medis. Kementrian Kesehatan. Jakarta.

[4] Republik Indonesia. 2004. UU No. 29 Tahun 2004 tentang Praktik Kedokteran Pasal 52. Jakarta

[5] Setyanto Arief. 2009. Mobile Medikal Records. STIMIK AMIKOM Yogyakarta.

[6] Suyanto Agung. 2013. Aplikasi Pengolahan Data SD N 009 Teluk Bintan. STTI Tanjungpinang.

[7] Syariff Sunata dan Mundir Faisal. 2008. Pengaruh Diferensiasi Produk Terhadap Keputusan Pembelian Flashdisk Kingston. Jurnal Pendidikan Manajemen Bisnis Universitas Pendidikan Indonesia Bandung.

[8] Tamara S. Almaya. 2013. Pembuatan Game Pendidikan "Learning Korean". Universitas AMIKOM Yogyakarta.

[9] Yasa Gd A. W. Setia dkk. 2012. Produk Casing Flash disk Berbahan Tulang Dan Resin Di Home Industri "Bali Poenya" Kediri, Tabanan, Bali. e-Journal Universitas Pendidikan Ganesha Jurusan Pendidikan Seni Rupa (Volume X).

\section{SEKILAS TENTANG PENULIS}

Saya bernama Gratia Cintamy Pondaag dan merupakan anak pertama dari 2 bersaudara. Lahir di Amurang pada tanggal 19 Januari 1995.

Saya mulai menempuh pendidikan di TK GMIM Hanna Manado (1999-2000) kemudian melanjutkan ke sekolah dasar di SDN 20 Manado dan SDN 2 Mundung (20002006). Selanjutnya saya melanjutkan studi di SMP Khatolik Pax Chisti Manado (2006 - 2009) dan kemudian menempuh pendidikan ke sekolah menengah atas di SMA Khatolik Rex Mudi Manado (2009- 2012).

Di tahun 2012 saya melanjutkan pendidikan ke perguruan tinggi yang berada di Manado yaitu Universitas Sam Ratulangi Manado, dengan mengambil Program Studi S-1 Teknik Informatika di Jurusan Elektro Fakultas Teknik. Dan akhirnya saya telah dinyatakan lulus dengan hasil yang baik dan memuaskan. 
